\title{
Pentitols and Insulin Release by Isolated Rat Islets of Langerhans
}

\author{
BY W. MONTAGUE AND K. W. TAYLOR \\ Department of Medicine and Diabetic Department, King's College Hospital Medical School, \\ London, S.E. 5
}

(Received 4 April 1968)

\begin{abstract}
1. Insulin secretion was studied in isolated islets of Langerhans obtained by collagenase digestion of rat pancreas. In addition to responding to glucose and mannose as do whole pancreas and pancreas slices in vitro, isolated rat islets also secrete insulin in response to xylitol, ribitol and ribose, but not to sorbitol, mannitol, arabitol, xylose or arabinose. 2. Xylitol and ribitol readily reduce $\mathrm{NAD}^{+}$when added to a preparation of ultrasonically treated islets. 3. Adrenaline $(1 \mu \mathrm{M})$ inhibits the effects of glucose and xylitol on insulin release. Mannoheptulose and 2-deoxyglucose, however, inhibit the response to glucose but not that to xylitol. 4. The intracellular concentration of glucose 6-phosphate is increased when islets are incubated with glucose but not with xylitol, suggesting that xylitol does not promote insulin release by conversion into glucose 6-phosphate. 5. Theophylline $(5 \mathrm{~mm})$ potentiates the effect of $20 \mathrm{~mm}$-glucose on insulin release from isolated rat islets of Langerhans, but has no effect on xylitol-mediated release. These results indicate that xylitol does not stimulate insulin release by alterations in the intracellular concentrations of cyclic AMP. 6. A possible role for the metabolism of hexoses via the pentose phosphate pathway in the stimulation of insulin release is discussed.
\end{abstract}

Although glucose is the most important sugar that stimulates insulin release from the mammalian pancreas under physiological conditions, a number of other sugars are known to be as effective. Thus mannose stimulates insulin release both in vitro (Coore \& Randle, 1964) and in vivo (P. A. Rudnick \& K. W. Taylor, unpublished work), and the intravenous infusion of ribose into man may also cause a rapid rise in blood insulin (Steinberg, Ortman, Poucher, Cochran \& Gwinup, 1967).

The $\mathrm{C}_{5}$ polyhydric alcohol xylitol stimulates insulin release after infusion into the dog (Kuzuya, Kanazawa \& Kosaka, 1966) and into man (Maruhama et al. 1967). Since xylitol is known to be rapidly metabolized through the pentose phosphate pathway in mammalian tissues such as liver (Hollmann \& Touster, 1957) and adipose tissue (Mori, Kanatsuna \& Kuzuya, 1967), it seemed possible that xylitol might be metabolized by a similar pathway in the pancreatic $\beta$-cell.

The effects of a number of pentitols and pentoses on insulin release have now been studied in greater detail by using a preparation of isolated rat islets of Langerhans. A preparation of this type has the advantage that it allows estimation of metabolic intermediates such as glucose 6-phosphate to be made on cells active in secretion. The results are discussed in relation to the possible involvement of the pentose phosphate pathway in insulin release due to sugars. Some of these data have already been presented in a preliminary form (Montague, Howell \& Taylor, 1967).

\section{MATERIALS}

Sources of hormones and reagents for hormone assay. Ox insulin used as standards in the assay of insulin was a recrystallized specimen kindly provided by the Wellcome Research Laboratories, Beckenham, Kent. The sample of rat insulin was a gift from Dr A. J. Moody of the Novo Research Institute, Copenhagen, Denmark. Assays for insulin were performed with the immunoassay kit (code IM39) available from The Radiochemical Centre, Amer. sham, Bucks.

Crystalline glucagon, free of insulin, was generously given by Dr Mary Root of Lilly Laboratories Ltd., Indianapolis, Ind., U.S.A., and adrenaline was purchased from Sigma (London) Chemical Co. Ltd., London, S.W. 6.

Phosphate buffer, used for the immunoassay of insulin, consisted of $6 \cdot 2 \mathrm{~g}$. of $\mathrm{NaH}_{2} \mathrm{PO}_{4}, 2 \mathrm{H}_{2} \mathrm{O}, 0 \cdot 25 \mathrm{~g}$. of thiomersalate and $1.0 \mathrm{~g}$. of bovine serum albumin dissolved in 11 . of water, the $\mathrm{pH}$ being adjusted to $7 \cdot 4$ with $2 \mathrm{~N}-\mathrm{NaOH}$.

Organic chemicals. D-Glucose, D-mannose and glycerol of A.R. quality were obtained from Hopkin and Williams Ltd., Chadwell Heath, Essex. Sugars and sugar derivatives were the purest commercially available and were obtained from Sigma (London) Chemical Co. Ltd., except for mannoheptulose, which was purchased from Nutritional Biochemicals Corp. (U.K. distributors, Kodak Ltd., Kirkby, Liverpool). Theophylline was obtained from British Drug 
Houses Ltd., Poole, Dorset, and tolbutamide from Hoechst A.-G., Frankfurt/M, Germany.

Incubation medium. In all incubations with isolated rat islets of Langerhans the medium was a bicarbonate-buffered salt solution (Gey \& Gey, 1936). It was gassed for $10 \mathrm{~min}$. before use with $\mathrm{O}_{2}+\mathrm{CO}_{2}(95: 5)$, and bovine serum albumin fraction $\mathrm{V}(2 \mathrm{mg}$. $/ \mathrm{ml}$.) was added immediately before use. The albumin was purchased from the Armour Pharmaceutical Co. Ltd., Eastbourne, Sussex.

Enzymes. Collagenase (form II) was obtained from Koch-Light Laboratories Ltd., Colnbrook, Bucks. Other enzymes and nicotinamide nucleotides were from the Boehringer Corp. (London) Ltd., London, W. 5.

\section{METHODS}

Isolation of islets of Langerhans. Male albino Wistar rats weighing $350-400 \mathrm{~g}$. were used in all experiments. They were fed on MRC diet 41B as modified and produced by Oxoid Ltd., London, E.C. 4. Two rats were deprived of food overnight and the following morning were killed by a sharp blow across the neck. The splenic portion of each pancreas was rapidly removed and transferred into ice-cold medium. Islets of Langerhans were separated from the pancreatic acinar tissue with collagenase by the method of Howell \& Taylor (1968). It was possible to obtain 250 islets of Langerhans from the pancreatic tissue taken from two rats. These were incubated in medium containing $2 \mathrm{~mm}$-glucose for $30 \mathrm{~min}$. at $37^{\circ}$ under $\mathrm{O}_{2}+\mathrm{CO}_{2}(95: 5)$ before use in experiments.

Insulin secretion from isolated rat islets. For a study of the effects of one of the various agents on insulin secretion, a group of ten islets was incubated in $2.0 \mathrm{ml}$. of medium contained in a $10 \mathrm{ml}$. conical flask. The gas phase was $\mathrm{O}_{2}+\mathrm{CO}_{2}(95: 5)$, and the medium contained either glucose or the compound under study. The islets were incubated at $37^{\circ}$ for $30 \mathrm{~min}$. with gentle shaking and then $0.1 \mathrm{ml}$. of the medium was removed, diluted to $1.5 \mathrm{ml}$. with phosphate buffer, $\mathrm{pH} 7 \cdot 4$, and stored frozen at $-20^{\circ}$ before the estimation of insulin. Rates of insulin secretion from isolated rat islets were almost linear over at least $2 \mathrm{hr}$. incubation.

Assay of insulin. The radioimmunoassay of Hales \& Randle (1963) was used for the estimation of insulin. Ox insulin standards were used throughout, and were compared with a sample of rat insulin. No significant difference was observed in the immunological behaviour of rat and ox insulins when these were assayed in the range 0-50 $\mu$ units $/ \mathrm{ml}$. In the range 50-250 $\mu$ units $/ \mathrm{ml}$., however, some differences between the binding characteristics of rat and ox insulins in this assay became apparent, which would have resulted in an underestimation of rat insulin at higher concentrations. In all assays in the present work the insulin values measured were in the range $12-50 \mu \mathrm{units} / \mathrm{ml}$.

Determination of the glucose 6-phosphate content of islets. Isolated rat islets of Langerhans were incubated in groups of ten as described above for the study of insulin secretion. In each experiment the effects of $2 \mathrm{~mm}$ - and $20 \mathrm{~mm}$-glucose in the medium were compared with those of $2 \mathrm{~mm}$ - and $20 \mathrm{~mm}-x y$ litol, and six flasks were used at each concentration for both agents. After $30 \mathrm{~min}$. incubation at $37^{\circ}$, the medium was sampled for determination of its insulin content. The contents of each series of flasks were then transferred to separate pointed centrifuge tubes and the islets spun down for $15 \mathrm{sec}$. at $2000 \mathrm{rev} . / \mathrm{min}$. at room temperature. The medium was decanted from each tube and the tubes were rapidly cooled to $-76^{\circ}$ in a bath of ethanol and solid $\mathrm{CO}_{2}$. One of the tubes was then transferred from the ethanol bath to an ice bath, and $0.4 \mathrm{ml}$. of $6 \%(\mathrm{w} / \mathrm{v}) \mathrm{HClO}_{4}$ (kept at $0^{\circ}$ ) was added. The contents of the tube were then treated ultrasonically for 60 sec. by using an ultrasonic disintegrator fitted with a microtip attachment (Soniprobe type 1130A; Dawe Instruments Ltd., London, W. 3). The tubes and their contents were kept at $0^{\circ}$ during and after treatment by immersion of the tube in an ice bath. This procedure was repeated for each tube and the precipitated proteins were spun down. The supernatants were decanted and stored at $-20^{\circ}$ for the determination of glucose 6-phosphate concentrations the next day. With the small amount of tissue available (60 islets weigh approx. $0.5 \mathrm{mg}$. wet wt.) the glucose 6 phosphate concentrations in the $\mathrm{HClO}_{4}$ extracts were in the range $0 \cdot 01-0 \cdot 1 \mu \mathrm{M}$ and had to be estimated by using an enzyme cycling procedure (Lowry, Passonneau, Hasselberger \& Schutz, 1964). The acid extracts from the islets were allowed to thaw to $0^{\circ}$ and $5 \mathrm{M}-\mathrm{K}_{2} \mathrm{CO}_{3}$ was added to neutralize the $\mathrm{HClO}_{4}$. After $10 \mathrm{~min}$. at $0^{\circ}$ the precipitated $\mathrm{KClO}_{4}$ was spun off and samples $(0.1 \mathrm{ml}$.) were taken from the supernatants. Glucose 6-phosphate standards in $\mathrm{HClO}_{4}$ were neutralized as the samples; blanks were provided by neutralizing $\mathrm{HClO}_{4}$ with $\mathrm{K}_{2} \mathrm{CO}_{3}$. Duplicate determinations were made by using $0.1 \mathrm{ml}$. amounts of samples standards and blanks.

Effect of various polyols on the reduction of $N A D^{+}$added to an extract of islets. A group of 500 islets of Langerhans were suspended in $3 \mathrm{ml}$. of $0.01 \mathrm{M}$-tripotassium phosphate, in a pointed centrifuge tube. The tube was placed in an ice bath and all subsequent steps were carried out at $0^{\circ}$. The islets were then disrupted ultrasonically as described above. The $\mathrm{pH}$ of the extract was adjusted to about 4.0 with a few drops of $2 \mathrm{~N}-\mathrm{HCl}$, and the extract was allowed to stand for $15 \mathrm{~min}$. The $\mathrm{pH}$ was then adjusted to $7.8 \mathrm{with} 5 \%(\mathrm{w} / \mathrm{v})$ $\mathrm{KOH}$ (Blakley, 1951). Of this extract, $0.5 \mathrm{ml}$. was pipetted into a $1 \mathrm{~cm} . \times 1 \mathrm{~cm} . \times 3 \mathrm{~cm}$. silica fluorimeter cell, $0.5 \mathrm{ml}$. of $0.01 \mathrm{M}$-tripotassium phosphate added, and the contents were mixed. Then $0.1 \mathrm{ml}$. of a $1 \mathrm{~mm}$ solution of $\mathrm{NAD}^{+}$in $0.01 \mathrm{M}$-tripotassium phosphate was added and the fluorescence of NADH was read at 30 sec. intervals in an AmincoBowman spectrofluorimeter. The excitation and emission wavelengths used were $355 \mathrm{~m} \mu$ and $470 \mathrm{~m} \mu$ respectively, and the sensitivity was set at 30 , giving readings on the 0.01 scale. When the reading had become constant, $0.01 \mathrm{ml}$. of a $10 \mathrm{~mm}$ solution of polyol in $0.01 \mathrm{M}$-tripotassium phosphate was added and the fluorescence was measured at $30 \mathrm{sec}$. intervals. When a constant reading had been obtained, a further $0.01 \mathrm{ml}$. of a different polyol was added and the fluorescence was again recorded at $30 \mathrm{sec}$. intervals.

\section{RESULTS}

The variation of insulin secretion, in response to a particular agent, from this preparation of isolated rat islets of Langerhans in experiments performed on different days was small, and results from several experiments were pooled for statistical analysis. Thus, in a series of ten experiments performed on different occasions, the mean insulin secretion ( \pm s.D.) in response to $20 \mathrm{~mm}$-glucose ranged from 
Table 1. Effects of hexoses, tolbutamide and glucagon on insulin secretion by isolated rat islets of Langerhans incubated in vitro

Isolated rat islets of Langerhans were incubated for $30 \mathrm{~min}$. at $37^{\circ}$ in a bicarbonate-buffered medium containing albumin $(2 \mathrm{mg} . / \mathrm{ml}$.). The medium contained either hexose alone or hexose with glucagon or tolbutamide. Insulin secreted into the medium was measured immunologically (see the text). The effects on insulin secretion of all the substances tested were compared with those of $2 \mathrm{~mm}$ - or $6 \mathrm{~mm}$-glucose as controls in each experiment. The results are given as the means \pm S.D.; the numbers of observations are given in parentheses. * Indicates values significantly different from the low-glucose control value with $P<0.01$.

\begin{tabular}{|c|c|c|}
\hline Addition to the medium & $\begin{array}{l}\text { Concn. of } \\
\text { hexose } \\
(\mathrm{mM})\end{array}$ & $\begin{array}{c}\text { Insulin secreted } \\
(\mu \text { units } / 10 \text { islets } / \mathrm{min} .)\end{array}$ \\
\hline D-Glucose & $\begin{array}{r}2 \\
20\end{array}$ & $\begin{array}{l}18 \pm 5(40) \\
37 \pm 7(40)^{*}\end{array}$ \\
\hline D-Mannose & $\begin{array}{r}2 \\
20\end{array}$ & $\begin{array}{l}17 \pm 5(20) \\
38 \pm 8(20)^{*}\end{array}$ \\
\hline D-Fructose & 20 & $16 \pm 5(20)$ \\
\hline D-Galactose & 20 & $16 \pm 4(20)$ \\
\hline D-Glucose & 6 & $26 \pm 5(25)$ \\
\hline $\begin{array}{l}\text { D-Glucose + tolbutamide } \\
(200 \mu \mathrm{g} . / \mathrm{ml} .)\end{array}$ & 6 & $50 \pm 9(25)^{*}$ \\
\hline D-Glucose + glucagon & 6 & $49 \pm 5(20)^{*}$ \\
\hline
\end{tabular}

(5 $\mu \mathrm{g} . / \mathrm{ml}$.)
Table 2. Effects of pentoses, pentitols and hexose derivatives on insulin secretion by isolated rat islets of Langerhans incubated in vitro

The experimental conditions were as described in Table 1. The effects on insulin secretion of all substances tested were compared with those of $2 \mathrm{~mm}$ - and $20 \mathrm{~mm}$-glucose as controls in each experiment. The results are given as the means \pm S.D.; the numbers of observations are given in parentheses. * Indicates values significantly different from the 2 mM-glucose control with $P<0.01$.

\begin{tabular}{lcc}
\multicolumn{1}{c}{$\begin{array}{c}\text { Concn. of } \\
\text { Addition to the } \\
\text { medium }\end{array}$} & $\begin{array}{c}\text { derivative } \\
\text { der } \\
(\mathrm{mM})\end{array}$ & $\begin{array}{c}\text { Insulin secreted } \\
(\mu \text { units/10 islets/min.) }\end{array}$ \\
D-Glucose & 2 & $17 \pm 3(80)$ \\
D-Ribose & 20 & $38 \pm 4(80)^{*}$ \\
& 2 & $17 \pm 5(20)$ \\
Xylitol & 20 & $41 \pm 8(20)^{*}$ \\
& 2 & $16 \pm 5(20)$ \\
Ribitol & 20 & $45 \pm 7(20)^{*}$ \\
& 2 & $18 \pm 5(20)$ \\
D-Arabitol & 20 & $38 \pm 8(20)^{*}$ \\
D-Xylose & 20 & $13 \pm 4(20)$ \\
D-Arabinose & 20 & $19 \pm 6(20)$ \\
D-Mannitol & 20 & $20 \pm 5(20)$ \\
D-Sorbitol & 20 & $14 \pm 4(20)$ \\
Sodium glucuronate & 20 & $17 \pm 3(20)$ \\
& 20 & $18 \pm 3(20)$
\end{tabular}

above the values obtained with $2 \mathrm{~mm}$-glucose (Table 2).

The results in Table 3 show that adrenaline $(1 \mu \mathrm{M})$, 2-deoxyglucose (20 mM) and mannoheptulose $(15 \mathrm{~mm})$ all inhibited the stimulatory effect of glucose on insulin release, whereas the effect of xylitol on insulin release was inhibited only by adrenaline. Sodium pyruvate $(5 \mathrm{~mm})$ and glycerol $(5 \mathrm{~mm})$ appeared to be without effect on insulin secretion when these were tested in the presence of 2mm-glucose (Table 4).

The intracellular concentrations of glucose 6-phosphate obtained in isolated rat islets of Langerhans incubated in the presence of glucose and xylitol are shown in Table 5. There was increased glucose 6-phosphate accumulation in the presence of $20 \mathrm{~mm}$-glucose but not in the presence of $20 \mathrm{~mm}$-xylitol. The concentrations of glucose 6-phosphate obtained are in good agreement with those reported by Matschinsky (1967) for rat islets. They are also similar to those reported by Coore, Hellman, Idahl \& Täljedal (1967) for islets obtained from obese hyperglycaemic mice in which the $\beta$-cells constitute over $90 \%$ of the islet tissue.

Table 6 shows the effects of $5 \mathrm{~mm}$-theophylline on the release of insulin from isolated rat islets due to glucose and xylitol. Theophylline potentiated 
Table 3. Effects of 2-deoxyglucose, mannoheptulose and adrenaline on the release of insulin in response to xylitol and glucose from isolated rat islets of Langerhans incubated in vitro

The experimental conditions were as described for Table 1. In each experiment the effects of $20 \mathrm{~mm}$-xylitol and 20 mm-glucose on insulin secretion were compared in both the absence and the presence of inhibitors. The results are given as the means \pm s.D.; the numbers of observations are given in parentheses. * Indicates values significantly different from the controls with $P<0.01$.

Insulin released in response to 20 mm-glucose ( $\mu$ units/10 islets/min.)

$\begin{array}{cc}\text { Inhibitor } & \begin{array}{c}\text { Inhibitor } \\ \text { absent }\end{array} \\ 39 \pm 6(15) & 25 \pm 6(15)^{*} \\ 41 \pm 6(15) & 24 \pm 6(15)^{*} \\ 40 \pm 7(15) & 21 \pm 4(15)^{*}\end{array}$

Insulin released in response to 20 mM-xylitol ( $\mu$ units/10 islets/min.)

\begin{tabular}{cc}
\hline $\begin{array}{c}\text { Inhibitor } \\
\text { absent }\end{array}$ & $\begin{array}{c}\text { Inhibitor } \\
\text { present }\end{array}$ \\
$44 \pm 8(20)$ & $45 \pm 8(20)$ \\
$40 \pm 4(20)$ & $40 \pm 6(20)$ \\
$47 \pm 5(30)$ & $20 \pm 5(20)^{*}$
\end{tabular}

Table 4. Effects of pyruvate and glycerol on insulin release by isolated rat islets of Langerhans incubated in the presence of glucose

The experimental conditions were as described for Table 1. The effects of $2 \mathrm{~mm}$ - and $20 \mathrm{~mm}$-glucose on insulin release were compared with those of $2 \mathrm{~mm}$-glucose plus $5 \mathrm{~mm}$-sodium pyruvate or $5 \mathrm{~mm}$-glycerol. The results are given as the means \pm S.D. and the numbers of observations are given in parentheses. * Indicates values significantly different from the 2 mM-glucose control with $P<0.01$.

$\begin{array}{ccc}\begin{array}{c}\text { Addition to the } \\ \text { medium }\end{array} & \begin{array}{c}\text { Concn. of } \\ \text { glucose } \\ (\mathrm{mM})\end{array} & \begin{array}{c}\text { Insulin secreted } \\ (\mu \text { units/10 islets/min.) }\end{array} \\ \begin{array}{c}\text { Glucose } \\ \text { Gucose+sodium }\end{array} & 2 & 17 \pm 3(40) \\ \text { ruvate } & 2 & 18 \pm 4(20) \\ \text { Glucose+glycerol } & 2 & 18 \pm 4(20) \\ \text { Glucose } & 20 & 40 \pm 6(40)^{*}\end{array}$

secretion of insulin in response to $20 \mathrm{~mm}$-glucose but was without effect on release due to xylitol.

\section{DISCUSSION}

Use of the isolated islet to study insulin secretion. The use of collagenase for isolating islets of Langerhans from pancreatic tissue may be questioned, because of the effect a proteolytic enzyme might have on the integrity of the structure of the islet cells. Nevertheless, in all studies made so far on insulin secretion, islets isolated by the use of collagenase have behaved similarly to islets in other pancreatic tissue preparations. This was so in the present experiments. Similar results to these were obtained by Lacy \& Kostianovsky (1967), who studied secretion from collagenase-prepared rat islets. Further, such islets have not been shown to be metabolically different from islets obtained by microdissection. Thus Asheroft, Coll-Garcia, Gill \&
Randle (1968) showed that islets isolated from mouse pancreas, either by collagenase or by microdissection, oxidize $\left[{ }^{14} \mathrm{C}\right]$ glucose to ${ }^{14} \mathrm{CO}_{2}$ at a rate proportional to the glucose content of the medium. It is assumed, on all this evidence, that collagenase-treated islets provide a suitable model system for the study of insulin secretion in vitro.

Effect of pentoses and pentose derivatives on insulin secretion. Our observations in vitro (Table 2) are in agreement with those of several other investigators who have shown that ribose and xylitol produce a rapid rise in plasma insulin when infused into man or dog (Steinberg et al. 1967; Maruhama et al. 1967; Kuzuya et al. 1966; Hirata, Fujisawa, Sato, Asano \& Katsuki, 1966). From Table 2, ribitol is also seen to be a very effective agent in inducing insulin release; an effect of this kind had not hitherto been reported for ribitol. It is concluded that ribose, xylitol and ribitol stimulate insulin secretion by a direct effect on the islets of Langerhans.

Metabolism of pentitols in mammalian tissues. Many investigators have shown that xylitol is rapidly metabolized by mammalian tissues. Thus there is a rapid decrease in blood xylitol concentrations after infusion into man, with only a small urinary loss (Mehnert, Bässler \& Förster, 1967); Krebs, Notton \& Hems (1966) showed that xylitol is rapidly metabolized to glycogen and glucose in mouse liver; and in adipose tissue xylitol carbon is rapidly incorporated into carbon dioxide, lipid, the glycerol of glycerides and fatty acids (Mori et al. 1967).

It has been demonstrated that in liver there is an NAD-linked dehydrogenase that rapidly oxidizes certain polyols to ketose sugars (McCorkindale \& Edson, 1954). The present results indicate that a dehydrogenase also exists in islet tissue that oxidizes xylitol and ribitol.

Possible mechanism for the effect of xylitol on secretion. Xylitol-induced secretion of insulin appeared not to be affected by concentrations of 


\section{Table 5. Intracellular concentration of glucose 6-phosphate in isolated rat islets of Langerhans used to} study insulin secretion in response to glucose and xylitol

Isolated rat islets of Langerhans were incubated as described in Table 1. The effects on insulin secretion of $2 \mathrm{~mm}$ - and $20 \mathrm{~mm}$-glucose were compared with those of $2 \mathrm{~mm}$ - and $20 \mathrm{~mm}$-xylitol. The experimental procedure is described in the Methods section. The results are given as the means \pm S.D.; the numbers of observations are given in parentheses. * Indicates values significantly different from the 2 mM-glucose control with $P<0.01$.

$\begin{array}{cccc}\begin{array}{c}\text { Addition to the } \\ \text { medium }\end{array} & \begin{array}{c}\text { Concn. of sugar } \\ \text { or pentitol } \\ (\mathrm{mm})\end{array} & \begin{array}{c}\text { Concn. of glucose } \\ 6 \text {-phosphate } \\ (\mu \mu \text { moles/40 islets) }\end{array} & \begin{array}{c}\text { Insulin secreted } \\ \text { ( } \mu \text { units/10 islets/min.) }\end{array} \\ \begin{array}{c}\text { D-Glucose } \\ \text { D-Glucose }\end{array} & 2 & 24 \cdot 5 \pm 4 \cdot 0(8) & 17 \pm 4(30) \\ \text { Xylitol } & 20 & 55 \cdot 0 \pm 9 \cdot 0(8)^{*} & 39 \pm 6(30)^{*} \\ \text { Xylitol } & 2 & 18 \cdot 0 \pm 3 \cdot 0(8) & 18 \pm 4(30) \\ & 20 & 20 \cdot 0 \pm 3 \cdot 0(8) & 44 \pm 7(30)^{*}\end{array}$

Table 6. Effects of theophylline on the secretion of insulin in response to xylitol and glucose by isolated rat islets of Langerhans

The experimental conditions were as described for Table 1. The incubations were carried out in the presence of glucose or xylitol with and without $5 \mathrm{~mm}$-theophylline. The results are given as the means \pm S.D.; the numbers of observations are given in parentheses. * Indicates a value significantly different from the control without theophylline with $P<0.01$.

Addition to the medium

\section{D-Glucose}

D-Glucose + theophylline D-Glucose

D-Glucose + theophylline

Xylitol

Xylitol+theophylline

Xylitol

Xylitol+theophylline

\section{Concn. of} sugar or pentitol

Insulin secreted (mM) ( $\mu$ units/10 islets/min.)

$\begin{array}{rl}2 & 16 \pm 3(20) \\ 2 & 15 \pm 3(20) \\ 20 & 37 \pm 6(20) \\ 20 & 54 \pm 7(20)^{*} \\ 2 & 18 \pm 3(20) \\ 2 & 17 \pm 3(20) \\ 20 & 40 \pm 6(20) \\ 20 & 41 \pm 6(20)\end{array}$

mannoheptulose that markedly suppress insulin secretion due to glucose (Table 3 ). This would be expected if xylitol is metabolized by the pentose phosphate pathway, since the site of action of mannoheptulose is believed to be at the level of glucose phosphorylation (Coore \& Randle, 1964).

2-Deoxyglucose also failed to inhibit the secretion of insulin induced by xylitol, though in the same experiments it proved to be a very effective inhibitor of glucose-induced secretion (Table 3). The rapid metabolism of xylitol to glycogen in the liver raises the possibility that xylitol is metabolized to glucose 6-phosphate in the pancreatic $\beta$-cell in order to stimulate insulin release, through the reactions of the pentose phosphate pathway described by Horecker, Gibbs, Klenow \& Smyrniotis (1954). The results of experiments in which 2-deoxyglucose was used make this unlikely, since 2-deoxyglucose inhibits the enzyme phosphohexose isomerase (Wick, Drury, Nakada \& Wolfe, 1957).

More convincing evidence that xylitol is not converted into glucose 6-phosphate came from the direct measurement of glucose 6-phosphate concentrations in islets incubated in the presence of glucose and xylitol. The results in Table 5 clearly show that there is an increased accumulation of glucose 6-phosphate in islets incubated in the presence of $20 \mathrm{~mm}$-glucose in comparison with those with $2 \mathrm{~mm}$-glucose, but that there is no increase in the presence of $20 \mathrm{~mm}$-xylitol, even though insulin secretion is stimulated to the same extent.

The possibility that xylitol is metabolized to L-xylulose by an NADP.linked dehydrogenase, as occurs in liver (Hollmann \& Touster, 1957), and that the accumulation of reduced coenzyme is the signal for release seemed unlikely, since the metabolism of ribose and ribitol could not readily give rise to NADPH. Further, though an active NADP. linked glutamate dehydrogenase has been demonstrated in rabbit islets (Kissane, Lacy, Brolin \& Smith, 1964), glutamate does not stimulate the release of insulin from the pancreas of this species (Coore \& Randle, 1964).

A further method by which xylitol could influence insulin secretion is by its metabolism to $\mathbf{C}_{3}$ compounds such as phosphoglyceraldehyde. However, $5 \mathrm{~mm}$-glycerol itself is ineffective in promoting release, as is $5 \mathrm{~mm}$-pyruvate (Table 4). It is inferred that $\mathbf{C}_{3}$ compounds derived from sugars do not directly promote the secretion of insulin.

Several investigators have studied the effect of theophylline on insulin secretion and have shown that adenosine $3^{\prime}, 5^{\prime}$-(cyclic)-monophosphate (cyclic AMP) may have an important role in this (Turtle, Littleton \& Kipnis, 1967 ; Malaisse, Malaisse-Lagae \& Mayhew, 1967). It is generally assumed that theophylline is effective in enhancing secretion 
from glandular tissue by the inhibition of cyclic phosphodiesterase (Butcher \& Sutherland, 1962), resulting in increased intracellular concentrations of cyclic AMP. Malaisse et al. (1967) suggested that the effects of theophylline on glucose-mediated insulin release are due to the stimulation of phosphorylase by the increased concentrations of cyclic AMP, resulting in an increased breakdown of islet-cell glycogen. They also showed that this effect can only be obtained when islet tissue is incubated in high concentrations of glucose, conditions that favour the accumulation of glycogen. By contrast, the effects of xylitol on insulin release are not potentiated by theophylline (Table 6), and it is concluded that xylitol does not promote secretion of insulin by an increase in the intracellular concentrations of cyclic AMP in islet cells.

Connexion between glucose-induced insulin release and release due to xylitol. The inhibitory effect of mannoheptulose (Table 3) indicates that glucose has to be phosphorylated to stimulate insulin release (Coore \& Randle, 1964; Ashcroft \& Randle, 1968). Alternative pathways by which the further metabolism of glucose 6-phosphate may lead to insulin release are glycolysis, the glucuronic acid pathway, glycogen formation or the pentose phosphate pathway.

It is unlikely that the metabolism of glucose through glycolysis is important in the control of insulin secretion, since anoxia and 2,4-dinitrophenol, which would be expected to promote the utilization of glucose through this pathway, inhibit the secretory response to glucose (Coore \& Randle, 1964). Increased secretion of insulin takes place under conditions in which glycolysis is thought to be inhibited, for example in the presence of citrate or short-chain fatty acids (Montague \& Taylor, 1968). The involvement of the glucuronic acid pathway is also unlikely, since sodium glucuronate does not stimulate insulin secretion (Table 2). There is no evidence that glycogen synthesis plays any part in the control of insulin secretion.

If the metabolism of pentoses and pentose derivatives through the pentose phosphate pathway affects insulin secretion, then it is possible that glucose itself is metabolized through this pathway to promote insulin release. Adrenaline inhibits the effects of both glucose and xylitol on secretion (Table 3), indicating that both agents may be effective through a common adrenaline-sensitive pathway. The inhibitory effect of 2-deoxyglucose on secretion is also compatible with the metabolism of glucose through the pentose phosphate pathway in islet cells, since this agent has been shown to inhibit the enzyme glucose 6-phosphate dehydrogenase as well as phosphohexose isomerase (Barban, 1960).
The possibility that the pentose phosphate pathway plays some role in the secretion of insulin in response to glucose has been suggested by other workers. Thus a high activity of the enzymes of this pathway was demonstrated in islets from various species (Kissane et al. 1964), including man (Field, Johnson, Herring \& Weinberg, 1960). This is in contrast with the low activities for some of the enzymes of the glycolytic pathway demonstrated by Brolin \& Berne (1967) in mouse islets.

The present observations suggest that the pentose phosphate pathway is of major importance in insulin release due to glucose. It is not known at present how the further metabolism of pentoses may influence insulin secretion.

We thank Professor J. Anderson for advice and encouragement and Miss M. Sandiford for invaluable help. Financial assistance towards the cost of this work from the Medical Research Council (to K.W.T.) and the British Diabetic Association is gratefully acknowledged.

\section{REFERENCES}

Ashcroft, S. J. H., Coll-Garcia, E., Gill, J. R. \& Randle, P. J. (1968). Diabetologia, 4, 178.

Ashcroft, S. J. H. \& Randle, P. J. (1968). Lancet, i, 278.

Barban, S. (1960). Fed. Proc. 19, 385.

Blakley, R. L. (1951). Biochem. J. 49, 17.

Brolin, S. E. \& Berne, C. (1967). Metabolism, 16, 1024.

Butcher, R. W. \& Sutherland, E. W. (1962). J. biol. Chem. 237, 1244.

Coore, H. G., Hellman, B., Idahl, L.-A. \& Täljedal, I.-B. (1967). Opusc. med. 12, 285.

Coore, H. G. \& Randle, P. J. (1964). Biochem. J. 93, 66.

Field, J. B., Johnson, P., Herring, B. \& Weinberg, A. N. (1960). Nature, Lond., 185, 468.

Gey, G. O. \& Gey, M. K. (1936). Amer. J. Cancer, 27, 45.

Hales, C. N. \& Randle, P. J. (1963). Biochem. J. 88, 137.

Hirata, Y., Fujisawa, M., Sato, H., Asano, T. \& Katsuki, S. (1966). Biochem. biophys. Res. Commun. 24, 471.

Hollmann, S. \& Touster, O. (1957). J. biol. Chem. 225, 87. Horecker, B. L., Gibbs, M., Klenow, H. \& Smyrniotis, P. Z. (1954). J. biol. Chem. $207,393$.

Howell, S. L. \& Taylor, K. W. (1968). Biochem. J. 108, 17. Kissane, J. M., Lacy, P. E., Brolin, S. E. \& Smith, C. H. (1964). In The Structure and Metabolism of the Pancreatic Islets, p. 281. Ed. by Brolin, S. E., Hellman, B. \& Knutson, H. Oxford: Pergamon Press Ltd.

Krebs, H. A., Notton, B. M. \& Hems, R. (1966). Biochem. J. 101, 607.

Kuzuya, T., Kanazawa, Y. \& Kosaka, K. (1966). Metabolism, 15, 1149.

Lacy, P. E. \& Kostianovsky, M. (1967). Diabetes, 16, 35.

Lowry, O. H., Passonneau, J. V., Hasselberger, F. X. \& Schutz, D. W. (1964). J. biol. Chem. 239, 18.

McCorkindale, J. \& Edson, N. L. (1954). Biochem. J. 57, 518.

Malaisse, W. J., Malaisse-Lagae, F. \& Mayhew, D. (1967). J. clin. Invest. 46, 1724.

Maruhama, Y., Chiba, M., Anzai, M., Ohneda, A., Goto, Y.\& Yamagata, S. (1967). Abstr. 6th Congr. int. Diabetes Fed.; Excerpta med. no. 140, p. 44. 
Matschinsky, F. M. (1967). Fed. Proc. 26, 257.

Mehnert, H., Bässler, K. H. \& Förster, H. (1967). Abstr. 6th Congr. int. Diabetes Fed.; Excerpta med. no. 140, p. 132.

Montague, W., Howell, S. L. \& Taylor, K. W. (1967). Nature, Lond., 215, 1088.

Montague, W. \& Taylor, K. W. (1968). Nature, Lond., 217, 853.
Mori, K., Kanatsuna, T. \& Kuzuya, K. (1967). Abstr. 6th Congr. int. Diabetes Fed.; Excerpta med. no. 140, p. 161. Steinberg, T., Ortman, P., Poucher, R., Cochran, B. \& Gwinup, G. (1967). Metabolism, 16, 40.

Turtle, J. R., Littleton, G. K. \& Kipnis, D. M. (1967). Nature, Lond., 218, 727.

Wick, A. N., Drury, D. R., Nakada, H. I. \& Wolfe, J. B. (1957). J. biol. Chem. 224, 963. 